\title{
UTILIZATION OF CORK AS COOLER BAG MAKING MATERIALS FOR DAIRY BREAST MILK AS AN EXCLUSIVE BREAST MILK COVERAGE ON WORKING MOTHER
}

\author{
Bina Melvia Girsang ${ }^{1}$, Farida Linda Sari $^{2}$, Nur Afi Darti ${ }^{3}$ \\ 1) Maternity and Child Department, Faculty of Nursing, Universitas Sumatera Utara \\ E-mail: binamelvia@usu.ac.id \\ 2) Maternity and Child Department, Faculty of Nursing, Universitas Sumatera Utara \\ E-mail: binamelvia@usu.ac.id \\ 3) Maternity and Child Department, Faculty of Nursing, Universitas Sumatera Utara \\ E-mail: binamelvia@usu.ac.id
}

\begin{abstract}
Working mother factors, lack of knowledge about the benefits of breast milk, and the low support of assisting health workers are factors that influence the achievement of exclusive breast milk targets. The method of implementing community service activities was carried out with health counseling and assistance in the manufacture of milk bag milk milk cooler for 20 breastfeeding working mothers. Making cooler bags using cork as a material that is easily available and economical, is a breakthrough that can be made in helping to achieve exclusive breastfeeding programs. The purpose of this community service is to empower mothers through making cooler bags that are expected to improve the skills and confidence of working mothers in providing breast milk. The implementation of community service shows the results that mothers understand about the benefits of breast milk $(80 \%)$, the statement of the attitude of mothers who are willing to milk breast milk in the workplace $(80 \%)$, and all mothers are able to play a role in making cooler bags independently. Communities can learn independently (self learning) and can share experiences in preventing and tackling infant health, especially in fulfilling breast milk for infant growth and development
\end{abstract}

Keyword: Dairy Breast Milk, Cooler Bag, Cork

\section{INTRODUCTION}

Today's health development program in Indonesia is still prioritized in efforts to improve maternal and child health, especially in vulnerable groups, namely pregnant women, postpartum mothers, and newborns (Profile of Medan Deli Health Center, 2018). Various obstacles that can arise in efforts to provide breastfeeding, especially for working mothers (Astutik, 2014).

Indonesia is a country that absorbs a lot of labor, especially from mothers, as well as a country that is very low in the number of mothers who exclusively breastfeed their babies until they are 6 months old. The status of the mother working is not a problem in giving ASI every day, one of the efforts that can be done is by milking the milk and storing the milk ASI (ASIP) so that the benefits do not decrease. (Riksani, 2012). Facilities at work are often not supportive in providing temporary milk storage for mothers, mothers can use cooler bags to store milk that has been milked. Storage of breast milk in breast milk cooler can last up to 12-24 hours (Harris, 2018; NHS UK, 2016; Baby Center India, 2018).

The involvement and support of the husband, family, health personnel and work environment influences the mother's selfesteem to avoid worrying and anxiety that can affect the hormone oxytocin as a 
hormone that helps release milk. Selfconfident mothers can provide as much milk as needed by babies without having to be added to other foods such as formula milk (O’Brien. M, 2007). This is also stated in the Regulation of the Minister of Health of the Republic of Indonesia Article 14, which states that health workers need to deliver breastfeeding that can improve maternal and child health, work productivity, and mother's self confidence (PP Minister of Health of the Republic of Indonesia, 2013).

The environmental area of 1 city built is close $(<1 \mathrm{~km})$ to an industrial area. This is an opportunity for local residents to become a source of livelihood, especially for women working as factory workers. This is one of the factors that contributes to the low coverage of exclusive breastfeeding in the region. Based on profile data of Medan Deli Health Center, the achievement of exclusive breastfeeding target is $45.2 \%$, according to the data source, the coverage of exclusive breastfeeding is still low due to the lack of knowledge of the community (Profile of Medan Deli Health Center, 2018).

Mother's knowledge and understanding of ASI will determine the behavior to achieve exclusive breastfeeding. In the profile of the Medan Deli Health Center, it was also stated that counseling was needed for pregnant women, children, and their families to increase their knowledge and understanding of the status and nutritional needs of infants from the time they were in the womb (1000 days of life). The process of breastfeeding is a positive interaction between mother and baby. Mother's milk makes the baby more comfortable in the mother's arms and she will become a mature person Profile of Medan Deli Health Center, 2018).

\section{METHODS}

The method of implementing community service activities is carried out with health counseling and assistance.
1. Education Workers are concerned about the importance of continuing to provide breastfeeding so that the mother has knowledge of the importance of giving breast milk to mothers and babies

2. Providing support for working mothers to continue providing breast milk to babies so that working mothers are able to make the decision to continue breastfeeding

3. Empowerment Mother utilizes items in the surrounding environment to be efficient, such as cork so that you can use cork as an ingredient in making ASIP cooler bags

4. Enhancing the skills of mothers in making products of economic value, so that she was able to demonstrate how to make cooler bags independently

Participants in the activity were 26 working mothers breastfeeding and carried out in the work area of Posyandu Cempaka IB, Lingkungan I, Kota Bangun, Medan, North Sumatra.

\section{RESULT AND DISCUSSION}

The implementation of community service activities at the Cempaka IB Posyandu, Lingkungan I, Kota Bangun went well, with the number of participants 26 mothers working to breastfeed less than the target participants, namely 35 mothers working breastfeeding. Community service activities were also attended by health personnel from the Community Health Center as many as 2 people (1 midwife, 1 administrative staff as the representative of the head of Medan Deli Health Center, and 5 health cadres of the Cempaka IB Posyandu, Lingkungan I. 


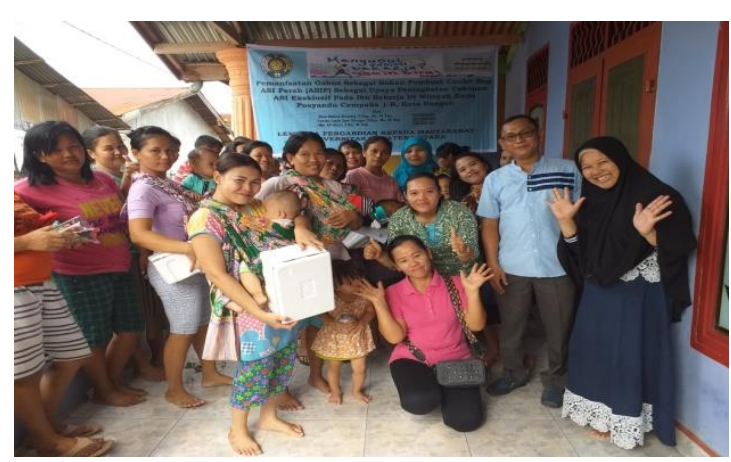

The majority of mothers were high school educators, while based on age characteristics, the average age of breastfeeding working mothers was 31.12 years old, the average number of children was 2 children. The following is a description of the characteristics of participants in community service activities (Table 1, 2).

Figure. 1 Participants in Community

Service Activities, Posyandu Cempaka IB, Lingkungan I Kota Bangun

Table 1. Frequency Distribution of Characteristics of Education for Working Mothers Breastfeeding the Posyandu Cempaka IB Working Area, Kota Bangun

\begin{tabular}{clcc}
\hline & Education Level & Frequency & Percentage (\%) \\
\hline 1. & Primary & 0 & 0 \\
2. Junior High School & 3 & 11,5 \\
3. Senior High School & & 22 & 84,6 \\
4. College & Total & 26 & 3,8 \\
& & 1 & 100 \\
\hline
\end{tabular}

Table 2. Descriptive Tables Age Characteristics and Number of Children Working Mother Breastfeeding Work Areas Posyandu Cempaka IB, Kota Bangun

\begin{tabular}{ccccccc}
\hline No & Variable & Mean & Min & Max & SD & SE \\
\hline 1 & Age & 31,12 & 23 & 40 & 31,00 & 1,01 \\
2 & Number of & 2,46 & 1 & 6 & 2 & 0,28 \\
& Children & & & & & \\
\hline
\end{tabular}

Education has a strong correlation with education, the higher the level of education of a person, the better his knowledge is expected, so that it can more easily receive and understand the information given to him. One of the factors that can describe physical maturity, psychological conditions, and one's social abilities are age factors. According to Sari, that the more increasing age in a person, the more one's knowledge will increase, because the more age-old a person will get more experience, especially in his behavior (Sari, 2012). 
Table 3. Frequency Distribution of Results of Community Service Survey, Posyandu Cempaka IB, Kota Bangun

\begin{tabular}{llccc}
\hline \multicolumn{2}{c}{ Survey Componen } & Frequency & Percentage(\%) \\
\hline 1 & Know about dairy & breast & & \\
milk & & 21 & 80,8 \\
1. Yes & 5 & 19,2 \\
2.No & 26 & 100
\end{tabular}

2 Willingness to blush breast milk at work

$\begin{array}{lcc}\text { 1.Yes } & 21 & 80,8 \\ 2 . \text { No } & 5 & 19,2 \\ \text { Total } & 26 & 100\end{array}$

3 Providing exclusive breastfeeding as long as the mother is working is not a difficult thing

$\begin{array}{lcc}1 . \text { Yes } & 12 & 46,2 \\ \text { 2.No } & 14 & 53,8 \\ \text { Total } & 26 & 100\end{array}$

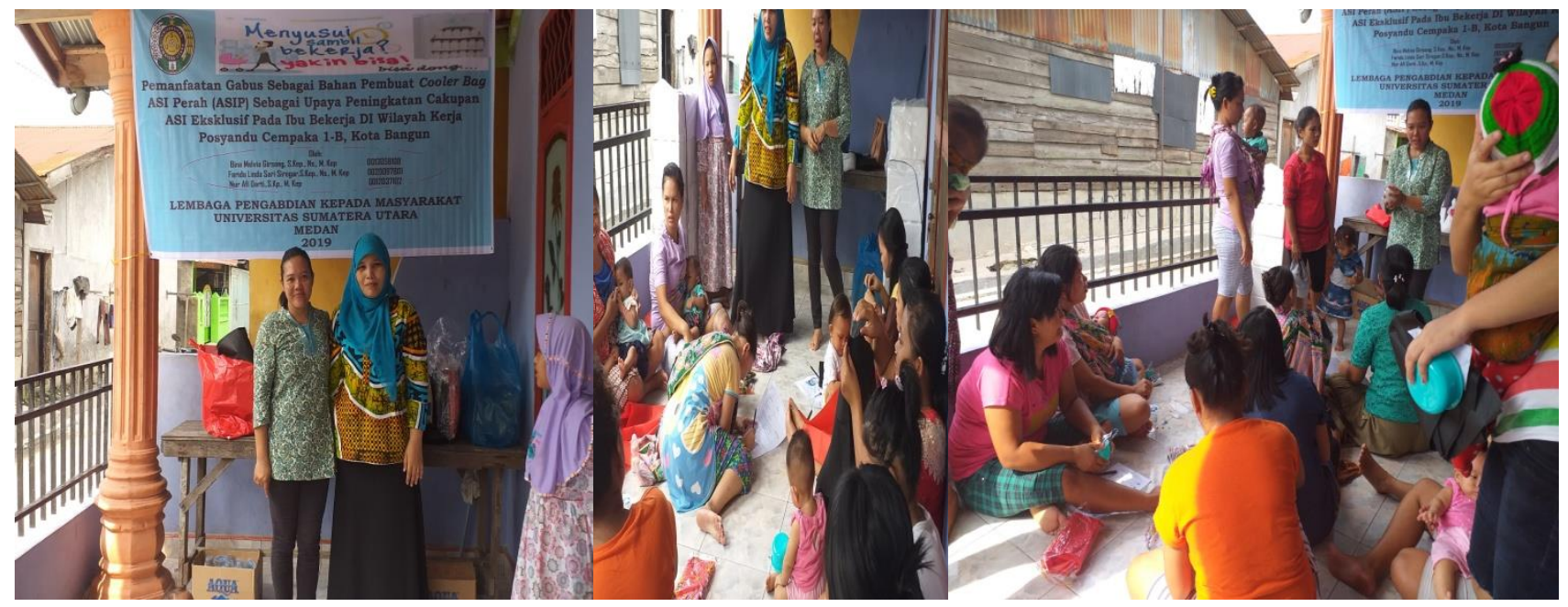

\section{Figure 2. Education about Dairy Breast Milk}

Education about dairy breast milk for mothers working and storing it is delivered first before assistance is given to making cooler bags. After the education the next session is to provide assistance in making cooler bags. All mothers were active in participating in the whole series of mentoring activities. This is evidenced from the results of the survey conducted by providing opportunities for all mothers to fill out the survey questionnaire. The survey results showed that the majority of mothers knew about dairy breast milk (80.8\%), a statement that mothers would pump ASIP in the workplace for adequate breastfeeding for babies during working mothers $(80.8 \%)$, and stated that giving exclusive breastfeeding during working mothers is not a difficult thing (53.8\%). 
Bina et.al. Utilization Of Cork As Cooler Bag Making Materials For Dairy Breast Milk As An Exclusive Breast Milk Coverage On Working Mother

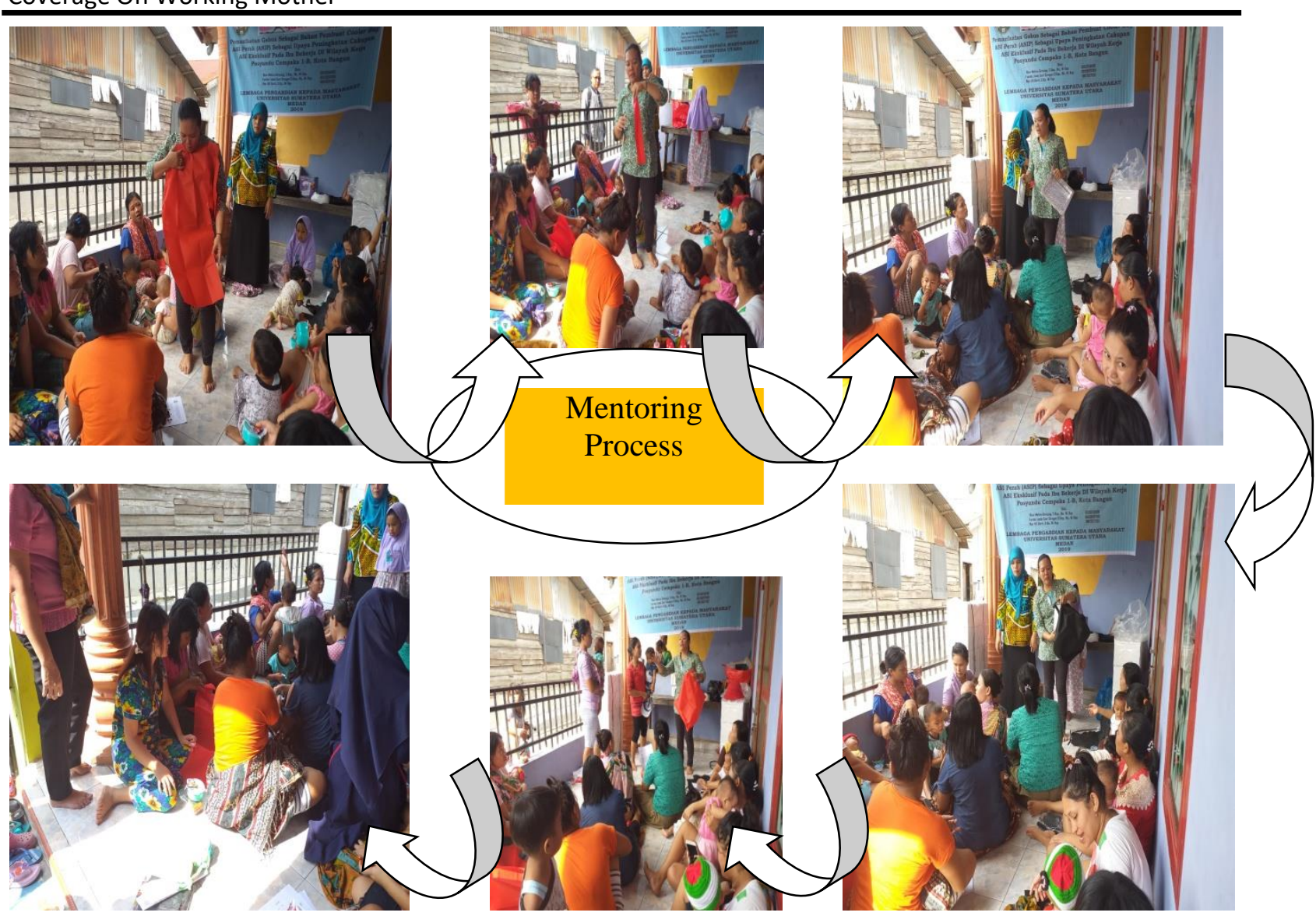

Figure 3. The Assistance Process for Making Dairy Breast Milk Coller Bag

The duration of working mothers has a correlation with the rate of growth of infants before the age of 4 months, where the rate of growth in infants with mothers works more slowly compared to mothers who do not work. The cause that could occur from this problem was stated by Novayenda, that there was a pattern of giving breast milk substitutes to formula feeding during maternity leave before returning to work, as a preparation for the adequacy of breastfeeding for her baby (Novayelinda, 2010).

The employment status of mothers who are breastfeeding should not be a barrier for mothers to provide breastfeeding if given good ASI management assistance during working mothers. Many problems that occur are that the mother does not do her role so that the needs of breast milk in infants are not sufficient for their growth and development, and the achievement of exclusive breastfeeding will also be difficult to achieve (Sodikin et al, 2008). Empowering mothers through mentoring mothers working breastfeeding in making milk ASI cooler bags by utilizing easily available corks.

This activity is expected to help independent mothers make decisions to breastfeed their babies, so that the coverage of the success of exclusive breastfeeding can be achieved. In addition to the mother's support, the mother can also be independent in preparing for optimal baby growth through the readiness of adequate breastfeeding for the baby. 

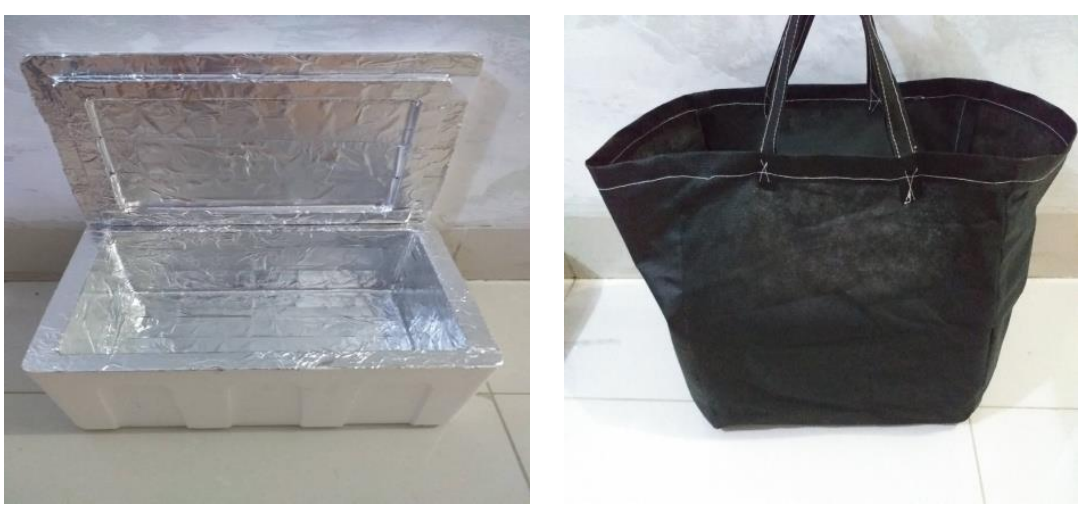

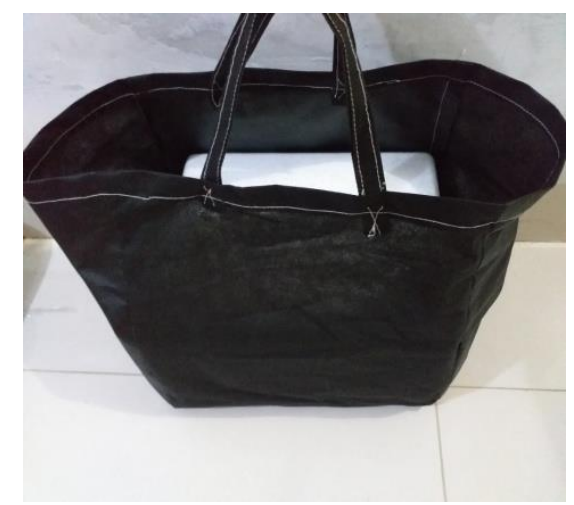

Figure 4. Dairy Breast Milk Cooler Bag

\section{CONCLUSION}

Health education about dairy milk can increase maternal knowledge well (80.8\%). Breastfeeding working mothers are able to express their attitudes to keep breastfeeding while working by milking breast milk during work $(80.8 \%)$, and claim to be able to breastfeed the baby before going to work.

Mentoring for making breast milk ASI cooler bags can also be well understood, where all mothers can make their milk ASI cooler bag independently after assistance. The independence of mothers can be trained through these community service activities, so that they are able and obtain support in supporting the success of achieving exclusive breastfeeding.

\section{ACKNOWLEDGEMENTS}

We would like to express our gratitude and appreciation to all of the parties involved in this project, especially to the Ministry of Research, Technology and Higher Education that made this project possible. We also would like to express our gratitude to the LPPM of University of Sumatera Utara which has provided guidance and motivation to our team until the very end of this project. To all related cadres who participated in supporting the implementation of community service activities at the Posyandu Cempaka IB, , the Community Health Center who attended and appreciated this activity, and all the mothers who worked breastfeeding were enthusiastic in attending this event.

\section{BIBLIOGRAPHY}

Astra Honda Training Center. 2015. Pelatihan Mekanik Tingkat I. Modul.

American Academy of Pediatrics. (2012). Policy statement: Breastfeeding and the use of human milk. Pediatrics, 15(2), 496-506

Astutik, Reni (2014). Payudara dan Laktasi. Jakarta: Salemba Medika

Baby Center India. 2018. Expressing Breastmilk at Work

Harris. K. The Bump. (2018). 10 Stylish Bags Built to Carry Your Breast Pump

NHS. UK. (2016). Health A-Z Expressing and StoringBreast Milk

Novayelinda, Rini. (2010) Telaah Literatur: Pemberian ASI dan Ibu Bekerja. (http://repository.usu.ac.id/bitstream/13 456789/32433/4/Chapter\%20II.pdf,acce ssed 22 June 2019)

O’Brien, ML. 2007. "I think I can"; Exploring the Influence of Psychological Factors on Breastfeeding Duration. Dissertation. University of Southern Queensland. 
Bina et.al. Utilization Of Cork As Cooler Bag Making Materials For Dairy Breast Milk As An Exclusive Breast Milk Coverage On Working Mother

Peraturan Menteri Kesehatan Republik Indonesia Nomor 15. (2013). Tata Cara Penyediaan Fasilitas Khusus Menyusui dan/atau memerah Air Susu Ibu.

Putri. (2015). Meningkatkan Kesuksesan Program ASI Eksklusif Pada Ibu Bekerja Sebagai Upaya Pencapaian MDG's. Jurnal Kesehatan Masyarakat Andalas (JKMA). P-ISSN 1978-3822. Vol.9 (2). 93-97

Puskesmas Medan Deli. (2018). Profil Puskesmas Medan Deli 2018

Riksani, R. (2012). Keajaiban ASI (Air Susu Ibu). Jakarta: Dunia Sehat

Margarettha, N. Safelia and Nasution, H. 2017a. Pengembangan Dan Pendampingan Pengrajin Songket Jambi. Jurnal Karya Abdi Masyarakat 1(1):1-6.

Margarettha, N. Safelia and H. Nasution. 2017 b. Pengembangan Songket Jambi melalui Pembinaan UKM in Pramono, R. and Parhusip, A. J. N. (Eds), Proceeding of Konferensi Nasional PKMCSR III 19-21 October 2017, Solo.pp. 145-151.

Marianti, M. M., and Istiharini. 2013. Analisis Karakteristik dan Perilaku Konsumen Tenun Songket Palembang. Research Report.

Bandung: Lembaga Penelitian dan Pengabdian kepada Masyarakat Universitas Katolik Parahyangan.

Viatra, A. W., and Triyanto, S. 2014. Seni Kerajinan Songket Kampoeng Tenun di Indralaya, Palembang. Jurnal Ekspresi Seni. 16(2),168-183. 